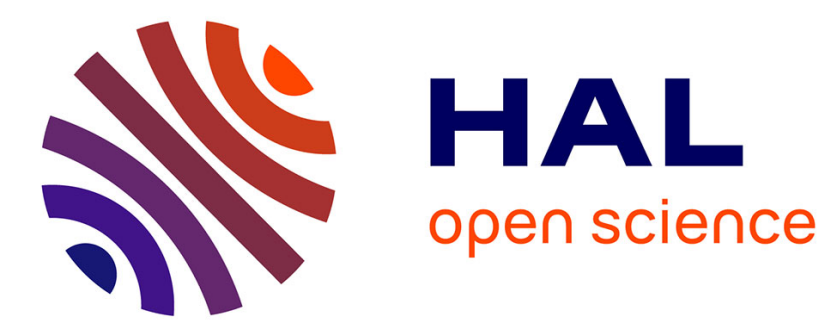

\title{
Utilization of interferometric light microscopy for the rapid analysis of virus abundance in a river
}

Céline Roose-Amsaleg, Yasmina Fedala, Catherine Vénien-Bryan, Josette Garnier, Albert-Claude Boccara, Martine Boccara

\section{To cite this version:}

Céline Roose-Amsaleg, Yasmina Fedala, Catherine Vénien-Bryan, Josette Garnier, Albert-Claude Boccara, et al.. Utilization of interferometric light microscopy for the rapid analysis of virus abundance in a river. Research in Microbiology, 2017, 10.1016/j.resmic.2017.02.004 . hal-01497684

\section{HAL Id: hal-01497684 https: / hal.sorbonne-universite.fr/hal-01497684}

Submitted on 29 Mar 2017

HAL is a multi-disciplinary open access archive for the deposit and dissemination of scientific research documents, whether they are published or not. The documents may come from teaching and research institutions in France or abroad, or from public or private research centers.
L'archive ouverte pluridisciplinaire HAL, est destinée au dépôt et à la diffusion de documents scientifiques de niveau recherche, publiés ou non, émanant des établissements d'enseignement et de recherche français ou étrangers, des laboratoires publics ou privés. 
For publication

2

Utilization of interferometric light microscopy for rapid analysis of virus

Céline Roose-Amsaleg ${ }^{\mathrm{a}^{*}}$, Yasmina Fedala ${ }^{\mathrm{b}, \mathrm{c}}$, Catherine Vénien-Bryan ${ }^{\mathrm{d}}$, Josette Garnier ${ }^{\mathrm{a}}$,

Albert-Claude Boccara $^{\mathrm{c}}$, Martine Boccara ${ }^{\mathrm{b}, \mathrm{e}}$

${ }^{a}$ UMR 7619 METIS, Sorbonne Universités, CNRS, Univ Paris 06, EPHE, 4 place Jussieu, 75005 Paris, France. Tel.: +33 144276256, fax: +33 144274588

${ }^{b}$ Institut de Biologie de l'Ecole Normale Supérieure (IBENS), Ecole Normale Supérieure, PSL

${ }^{c}$ Institut Langevin, ESPCI ParisTech, PSL Research University, CNRS UMR 7587, 1 rue Jussieu,

${ }^{d}$ Institut de Minéralogie, de Physique des Matériaux et de Cosmochimie UMR 7590, Sorbonne Universités, Univ Paris 06, CNRS, MNHN, IRD, 4 place Jussieu, 75005 Paris, France

${ }^{e}$ Atelier de Bioinformatique, UMR 7205 ISYEB Sorbonne Universités, Univ Paris 06, CNRS, MNHN,

*Correspondence and reprints.

E-mail addresses:

celine.amsaleg@upmc.fr (C. Roose-Amsaleg)*

yasmina.fedala@gmail.com

boccara.martine@gmail.com

Catherine.Venien@impmc.upmc.fr

josette.garnier@upmc.fr

claude.boccara@espci.fr 
27 Abstract

There is a constant need for direct counting of biotic nanoparticles such as viruses to

29 unravel river functioning. We used, for the first time in freshwater, a new method based on

30 interferometry differentiating viruses from other particles such as membrane vesicles. In the

31 French Marne River, viruses represented between 42 and $72 \%$ of the particles. A spring

32 monitoring in 2014 revealed their increase $\left(2.110^{7}-2.110^{8} \mathrm{~mL}^{-1}\right)$ linked to an increase in algal

33 biomass and diversity of bacterial plankton. Predicted virus size distributions were in 34 agreement with transmission electron microscopy analysis suggesting a dominance of large 35 viruses $(\geq 60 \mathrm{~nm})$.

36

37 Keywords: Virus; Membrane vesicle; Interferometric light microscopy; River 


\section{Introduction}

Water from the Marne River, one of the major tributaries of the Seine River, is used for the production of drinking water for most of the inhabitants of Paris and surroundings. The Marne River used to be subjected to high levels of nutrients (nitrogen and phosphorus), originating from intensive agriculture and urban impact which entailed uneven and recurrent development of algae. These algal blooms were mostly due to diatoms, and secondarily to Chlorophyceae, cyanobacteria forming only low populations in lotic systems [1-3]. Since the 2000s, with the EU Water Framework Directive (2000/60/CE), phosphorus has been considerably reduced $[4,5]$. Algal blooms have become scarce, except in dry years. These blooms are mainly observed in spring, when the dilution rate by the discharge becomes lower than algal growth rate. These algal blooms constitute a significant inconvenience for the production of drinking water as, in addition to clogging filters, they increase the water $\mathrm{pH}$ [2]. Algal dynamics have been extensively studied for 25 years in order to improve their growing prediction by modeling [6], without explicitly considering the ecological effect of viruses.

In any aquatic environment, viruses, about ten times more abundant than bacteria, control the algal and microbial diversity by lysis and may influence biogeochemical cycles. The abundance of aquatic viruses fluctuates over time, especially with the seasons. A peak of concentration is usually observed during spring-summer periods in surface waters; conversely, a significant decline occurs in autumn-winter [7]. The most common aquatic viruses of phytoplankton are double-stranded DNA-tailed viruses (Caudovirales) such as the following families: Myovirus (head size: $60-145 \mathrm{~nm}$ ), Podovirus (60-70 nm) and Siphovirus (40-80 nm) which infect prokaryotes while PhycoDNA viruses (large DNA viruses, 100-220 $\mathrm{nm}$ ) or picorna-like viruses (RNA viruses, 35nm) infect eukaryotic algae [7]. 
64

since it allows virus morphotypes to be counted and characterized [9], but is highly timeconsuming. Optical methods based on epifluorescence microscopy to detect double-stranded DNA binding fluorophores such as DAPI or SYBR are used extensively. However, these methods are adapted neither for detection of single-stranded DNA, nor RNA viruses [10]. Flow cytometry is also frequently used to enumerate viruses in natural viral assemblages [11]. Most previous methods need expensive equipment and do not distinguish viruses from extracellular membrane vesicles. Extracellular membrane vesicles are another type of aquatic environmental nanoparticle. Produced by organisms from the three domains of life, they are made of lipids and proteins and sometimes contain genetic material, and could thus be mistaken for viruses [12].

We used a new method suitable for all genetic material of viruses and able to differentiate viruses from membrane vesicles. The interferometric light microscope (ILM) combines two measurements for a single nanoparticle (30 to 100nm): its scattered signal and its Brownian motion. The scattered signal is a function of the size and refractive index (related to density) of the particle, while the Brownian motion is a function only of the size of the particle [13]. ILM was utilized to distinguish virus from other particles and then tested to explore the variations of viral communities in the Marne River in spring 2014, expected to be the algal bloom period. The discharge averaging $180 \mathrm{~m}^{3} \mathrm{~s}^{-1}$ in January-March decreased to 60 $\mathrm{m}^{3} \mathrm{~s}^{-1}$ during the studied period (April-May). The diversity of eukaryotic and bacterial communities was determined simultaneously. 
85

86

87

88

89

90

91

92

93

94

95

96

97

98

99

100

101

102

103

104

105

106

107

108

109

\section{Material and methods}

\subsection{Sample preparation}

Water was collected at Saint Maurice (5 km upstream from Paris, 4848'58.16" North, $002^{\circ} 25^{\prime 27.35 " ~ E a s t), ~ t h e ~ o u t l e t ~ o f ~ t h e ~ M a r n e ~ R i v e r, ~ a t ~ t h r e e ~ d a t e s ~ i n ~ 2014: ~ A p r i l ~} 1^{\text {st }}$ and $22^{\text {nd }}$ and May $14^{\text {th }}$. Samples were kept in an ice cooler during transport and filtered as soon as they arrived at the laboratory. Two liters of water were first filtered through $0.22 \mu \mathrm{m}$ filters (PolyVinyliDene Fluoride, Millipore) to collect eukaryotic and prokaryotic plankton. The filters were replaced every $0.5 \mathrm{~L}$ to avoid clogging. Filtrates (nanometric fraction) were then concentrated (10,000x) using a $30 \mathrm{KDa}$ cut off filter (Amicon, Millipore).

\subsection{Virioplankton characterization and interferometric data processing}

We analyzed $5 \mu \mathrm{L}$ of each filtrate (diluted in PBS to be 50x-concentrated) to collect a stack of 200 images (CMOS camera). The particles were first localized on each image and the average number per frame determined (volume $=10^{-8} \mathrm{~mL}$, concentration in particles of the sample). The maximum scattering intensity of each particle and its trajectory was computed [13]. With these data, we calculated the diameter of each particle from its scattering signal (diameter_scat) and from its Brownian diffusion (diameter_BM). Viral particles are the particles for which the two diameter measurements are close (refractive index $n=1.5$ ). The nanoparticle populations were resolved using the Mclust package of $\mathrm{R}$ software with default parameters. Particles for which the diameter_BM was over $20 \%$ larger than the diameter_scat were considered as empty capsids or vesicles.

\subsection{Transmission electron microscopy}

Samples (10 $\mu 1,10,000 x$-concentrated filtrates using Amicon $30 \mathrm{KDa}$ cut off filters) were applied to electron microscope hydrophilic grids coated with carbon film. The specimen was then negatively stained with $2 \%$ uranyl acetate. The preparations were examined using a 
110 Jeol 2100 electron microscope equipped with an LaB6 filament, with an acceleration voltage

111 of $200 \mathrm{kV}$ and a $2 \mathrm{~K}$ x $2 \mathrm{~K}$ Gatan CCD camera. The nominal magnification was $12.5 \mathrm{~K}$. Taking

112 into account the position of the camera, this gives a final magnification at the specimen level

113 of $17.8 \mathrm{~K}$. Therefore, the pixel size was $0.8 \mathrm{~nm}$. The pictures $(>20)$ were analyzed to count and

114 sort viruses. Viral capsid diameters were measured using ImageJ software (US National

115 Institutes of Health, Bethesda, MD, USA; [14]).

116

117

\subsection{Algal biomass}

Chlorophyll-a concentrations $(C h l-a)$ used as a proxy of the biomass of all 119 photosynthetic organisms were determined by spectrophotometry according to [15]. 
121

122

123

124

125

126

127

128

129

130

131

132

133

134

135

136

137

138

139

140

141

142

143

144

145

\section{Results and discussion}

\subsection{Virus-like particle direct counting from river water}

Using interferometric light microscopy, we counted particles in water samples previously filtered $(<0.2 \mu \mathrm{m})$ and concentrated $(50 \mathrm{x})$. We observed a sixfold increase in the total number of particles between the beginning $\left(510^{7} \mathrm{~mL}^{-1}\right.$, April $\left.1^{\text {st }}\right)$ and the end of the sampling $\left(310^{8} \mathrm{~mL}^{-1}\right.$, May $\left.14^{\text {th }}\right)$. We then analyzed the samples from a more qualitative point of view, calculating and plotting for each particle diameter_scat and diameter_BM. (Fig. 1). Indeed, any particle differing from a virus showed a similar movement, but a lower scattering signal [13]. We observed other dispersed particles that we predicted to be membrane vesicles [12]. Viruses therefore represented between $42 \%\left(2.110^{7} \mathrm{~mL}^{-1}\right.$, April $\left.1^{\text {st }}\right)$ and $72 \%\left(2.110^{8}\right.$ $\mathrm{mL}^{-1}$, May $14^{\text {th }}$ ) of the particles, in light of the first and last sampling date (Table 1). This analysis revealed that, in the studied river samples, the number of membrane vesicles could represent (by difference) 28-58\% of the detected particles. Estimating the number of membrane vesicles is a novelty which can provide new insight into the dynamics of viruses and their ecological importance.

\subsection{Viral population composition}

After excluding membrane vesicles from the analysis, viral populations were further characterized according to their size. Throughout the study, we observed two major peaks centered at 45 and $60 \mathrm{~nm}$ diameters (Fig. 2). We classified the predicted viruses into two groups (Table 1): medium-size diameters $(40-59 \mathrm{~nm})$ and larger diameters $(\geq 60 \mathrm{~nm})$. In addition to a general increase in the abundance of $45 \mathrm{~nm}$ viruses, the proportion of $\geq 60 \mathrm{~nm}$ viruses increased over time (from 7, $19 \%$ to $42 \%$, for April $1^{\text {st }}$ and $22^{\text {nd }}$ and May $14^{\text {th }}$, respectively). The viral population of $\geq 60 \mathrm{~nm}$ in size would correspond to myocyanophages and PhycoDNAviruses [16]. However, we detected neither small viruses (30 nm range, 
147 known to infect diatoms) nor very large viruses (>100nm, infecting freshwater green algae).

148 In fact, for particles larger than $100 \mathrm{~nm}$, there was no simple proportionality between the 149 scattering signal and the diameter with ILM [13].

150

152

153

154

155

156

157

158

159

160

161

162

163

164

165

166

167

\subsection{Comparison of interferometric light and transmission electron microscopy}

Using TEM, viruses were observed and counted by major family and sized (diameters). Viruses were classified as Myoviruses, Podoviruses, Siphoviruses or PhycoDNAviruses based on their morphology [16] or spherical particles (the last category corresponds to membrane vesicles, untailed viruses and cellular debris). The percentages of Siphoviruses and Podoviruses were stable between samples, while Myoviruses increased gradually (Fig. S2, S3). We were also able to detect Podoviruses and Myoviruses by DNA amplification (see supplementary information), only in the most virus-concentrated sample from May $14^{\text {th }}$ (data not shown). However the lack of reproducible amplification for Siphoviruses or PhycoDNAviruses suggested either that the amount of template was too small for proper amplification or that the degenerated primers were not suitable. Overall, while the proportion of prokaryotic viruses (Myoviruses and Siphoviruses and Podoviruses) increased (from 24 to 34\%), that of eukaryotic viruses (PhycoDNAviruses) decreased (from 9 to 5\%).

To compare the distribution of virus diameters between the TEM measurements with those obtained with ILM, we divided the samples into two groups: above and below $60 \mathrm{~nm}$ in diameter (Table 1). Although TEM is not a quantitative method, we observed the same distribution patterns for the two latter samples. However, we noticed a discrepancy for the first sample with a low viral concentration, suggesting that we need a threshold concentration of particles (of about $10^{9}$ particles $\mathrm{mL}^{-1}$, corresponding to at least an average number of 10 particles per frame) to reliably analyze samples by ILM. 


\subsection{Dynamics of photosynthetic populations during spring 2014 at Saint Maurice}

We observed a fivefold increase in Chl-a content between April $1^{\text {st }}\left(0.27 \mu \mathrm{g} \mathrm{L}^{-1}\right)$ and May $14^{\text {th }}\left(1.35 \mu \mathrm{g} \mathrm{L}^{-1}\right)$, suggesting slight algal growth, but not true algal bloom. Indeed, during a spring algal bloom in the Marne River basin, especially composed of diatoms, the

Chl-a concentration at St Maurice tended to reach $100 \mu \mathrm{g} \mathrm{L}^{-1}$ or more [1]. The last algal bloom was observed in May 2011 and produced $144 \mu \mathrm{g} \mathrm{L} \mathrm{L}^{-1}$ of total chlorophyll concentration jerri (Chl- $a$ and Pheopigments). On May 14, 2014, diatoms were responsible for $67 \%$ of the total algal biomass, with Cyanobacteria representing less than $0.1 \%$.

DNA fingerprinting methods such as PCR-DGGE enable diversity investigation from natural microbial communities by studying the pattern of operational taxonomic units (OTUs). Concerning the aquatic eukaryotic communities, we noted a similar number of OTU (i. e. an approximation of the species richness) between the beginning (April $1^{\text {st }}, 21 \pm 2.8$ OTU) and end of sampling (May 14 ${ }^{\text {th }}, 18 \pm 0$ OTU) (Fig. S1A). However, community composition showed a net modification, as the patterns of May $14^{\text {th }}$ showed a weak similarity percentage (43.2\%) with those of the other two dates.

In contrast, the species richness of aquatic bacterial communities (Fig. S1B) increased between early April and mid-May (from $13 \pm 0.7$ to $24 \pm 1.4$ OTU). Subsequently, the bacterial composition varied between dates: communities from April $1^{\text {st }}$ and May $14^{\text {th }}$ shared $43.1 \%$ of their OUT, whereas those of April $22^{\text {nd }}$ shared $33.2 \%$ with the other two dates.

Thus, in the studied station of the Marne River, over the short sampling period, prokaryotic viruses proliferated. This suggests that their hosts (whose the number of OTUs increased) would also be numerically dominant in the microbial community. In contrast, eukaryotic phytoplankton viruses became a minor part of the viral population, while their hosts harbored less richness (cf. OUT numbers). 
In conclusion, we have presented an analysis of virus abundance and diversity in a

196 lotic freshwater environment, the Marne River, during a growth phase of phytoplankton. To

197 analyze this viral abundance, we used an optical method based on interferometric light 198 microscopy. This method proved its efficacy even at a low algal level. With this method, we 199 observed an increase in virus particles and membrane vesicles which has not been previously 200 described in freshwater.

New ecological studies on viral dynamics in freshwater are needed to understand 202 how algal and bacterial dynamics are linked to viral communities and to possibly integrate 203 them into existing ecological models.

\section{Acknowledgments}

We would like to thank all the persons who helped us with the experiments: Ellie-

207 Arthur Siéwé-Bobda, Marc Bailly-Bechet, Benjamin Mercier, Fanny Hilaire and Hames 208 Mejri. Dr J-M Guigner is acknowledged for electron microscopy analysis. 


\section{References}

211 [1] Garnier J, Billen G, Coste M, Seasonal succession of Diatoms and Chlorophyceae in the drainage network of the Seine River - Observations and modeling. Limnol Oceanogr 1995;40:750-765.

214 [2] Garnier J, Némery J, Billen G, Thery S, Nutrient dynamics and control of eutrophication in the Marne River system: modelling the role of exchangeable phosphorus. J Hydrol 2005;304:397-412.

217 [3] Reynolds CS, Phytoplankton periodicity - the interactions of form, function and environmental variability. Freshwater Biol 1984;14:111-142.

[4] Passy $\mathrm{P}$ et al., A-model reconstruction of riverine nutrient fluxes and eutrophication in the Belgian Coastal Zone since 1984. J Marine Syst 2013;128:106-122.

[5] Aissa-Grouz N, Garnier J, Billen G, Long trend reduction of phosphorus wastewater loading in the Seine: determination of phosphorus speciation and sorption for modeling algal growth. Environ Sci Pollut R 2016;doi:10.1007/s11356-016-7555-7.

[6] Garnier J, Billen G, Production vs. Respiration in river systems: An indicator of an "ecological status". Sci Total Environ 2007;375:110-124.

226 [7] Jacquet S, Miki T, Noble R, Peduzzi P, Wilhelm S, Viruses in aquatic ecosystems: important advancements of the last 20 years and prospects for the future in the field of microbial oceanography and limnology. Adv Oceanogr Limnol 2010;1:97-141.

[8] Wommack KE, Nasko DJ, Chopyk J, Sakowski EG, Counts and sequences, observations that continue to change our understanding of viruses in nature. J Microbiol 2015;53:181192.

[9] Breitbart M, Marine Viruses: Truth or Dare. Ann Rev Mar Sci 2012;4:425-448.

233 [10]Forterre P, Soler N, Krupovic M, Marguet E, Ackermann HW, Fake virus particles generated by fluorescence microscopy. Trends Microbiol 2013;21:1-5. 
235 [11]Brussaard CPD, Enumeration of bacteriophages using flow cytometry. Methods Mol. Biol. $236 \quad 2009 ; 501: 97-111$

237 [12] Soler N., Krupovic M, Marguet E, Forterre P, Membrane vesicles in natural environments: 238 a major challenge in viral ecology. Isme J 2015;9:793-796.

239 [13]Boccara M, Fedala Y, Venien-Bryan C, Bailly-Bechet M, Bowler C, Boccara AC, Full240 field interferometry for counting and differentiating aquatic biotic nanoparticles: from 241 laboratory to Tara Oceans. Biomed Opt Express 2016;7:3736-3746.

242 [14]Abramoff MD, Magalhaes PJ, Ram SJ, Image Processing with ImageJ. Biophotonics $243 \quad$ International 2004;11:36-42.

244 [15]Lorenzen C J, Determination of Chlorophyll and Pheopigments - Spectrophotometric 245 equations. Limnol Oceanogr 1967;12:343.

246 [16]King AMQ, Adams. MJ, Carstens. EB, Lefkowitz EJ, Virus Taxonomy: Classification and 247 Nomenclature of Viruses: Ninth Report of the International Committee on Taxonomy of $248 \quad$ Viruses. Elsevier, 2011. 


\section{Legends to figure}

Fig. 1.Analysis of particles present at the Saint Maurice station, an outlet of the Marne River.

Plot of the diameters of particles computed with their scattered signals (Diameter_scat) and Brownian motion (Diameter_BM). Lines indicate refractive indexes of the different particles (viruses and vesicles). The colored bar corresponds to the relative number of characterized particles: the different colors correspond to the Matlab histogram plotted in normalized linear scale. The viruses that possess a refractive index of 1.5 are likely close to this line, while the rest of the particles could be vesicles.

\section{Fig. 2. Analysis of predicted viral particles from the Saint Maurice station.}

The scattered signals of individual particles were resolved using the Mclust package of $\mathrm{R}$ software in two populations (curves: $1 \mathrm{red}, 2$ blue and in black, the sum of all curves). The number of particles, mean diameters and variances in populations 1 and 2 are noted in the inset. 
Table 1: Comparison of analyzed viral particles by interferometric light (ILM) and transmission electron microscopy (TEM).

\begin{tabular}{|c|c|c|c|c|c|c|c|c|}
\hline & \multirow[b]{2}{*}{$\begin{array}{c}\text { Particle } \\
\text { concentrations } \\
\text { in the water } \\
\text { column } \\
\left(\mathbf{m L}^{-1}\right)\end{array}$} & \multicolumn{4}{|c|}{$\begin{array}{c}\text { Interferometric light microscopy }^{\mathfrak{E}} \\
\text { ILM }\end{array}$} & \multicolumn{3}{|c|}{$\begin{array}{c}\text { Transmission electron microscopy } \\
\text { TEM }\end{array}$} \\
\hline & & $\begin{array}{c}\text { Number } \\
\text { of } \\
\text { particles }^{\#}\end{array}$ & $\begin{array}{l}\text { Number of } \\
\text { predicted } \\
\text { viruses } \\
\text { (\% vs. } \\
\text { particles) }\end{array}$ & $\begin{array}{l}<60 \mathrm{~nm} \\
(\%)\end{array}$ & $\begin{aligned} \geq 60 \mathrm{~nm} \\
(\%)\end{aligned}$ & $\begin{array}{l}\text { Number of } \\
\text { particles }\end{array}$ & $\begin{array}{l}<60 \mathrm{~nm} \\
(\%)\end{array}$ & $\begin{aligned} \geq & 60 \mathrm{~nm} \\
& (\%)\end{aligned}$ \\
\hline April 1 & $510^{7}$ & 331 & $141(42)$ & 93 & 7 & 174 & 74 & 26 \\
\hline April 22 & $810^{7}$ & 830 & $535(64)$ & 81 & 19 & 172 & 67 & 33 \\
\hline May 14 & $310^{8}$ & 2243 & $1625(72)$ & 58 & 42 & 308 & 74 & 26 \\
\hline
\end{tabular}

268

$269{ }^{\mathfrak{E}}$ The same samples were concentrated 50 or 10,000 times for ILM and TEM, respectively

270 \#Number of particles for which we measured the diameter by scattering signal and by Brownian motion.

271 Number of particles analyzed from about 20 TEM images. 


\section{Supplementary material for on-line submission}

$P C R-D G G E$

Genomic DNA was extracted in duplicate from PVDF filters (Millipore) using the PowerSoil DNA isolation kit (MO BIO Laboratories, Inc). Amplification was performed with specific primers for DGGE (Table S1) to amplify fragments from $16 \mathrm{~S}$ and $18 \mathrm{~S}$ ribosomal DNA to study bacterial and eukaryotic diversity, respectively. Denaturing gradient gel electrophoresis (DGGE) was performed using the Phor-U system (Ingeny) as described in [1]. All PCR products were run on a single gel for the $16 \mathrm{~S}$ and another for the $18 \mathrm{~S}$. After 282 development of the DGGE polyacrylamide gel, each image was analyzed to determine similarities between profiles using the software GelCompar II 6.6 (Applied, Math). Each of the two gels was normalized based on an external reference pattern (the $100 \mathrm{bp}$ ladder, Invitrogen) required by the software to compare lanes. Each band of a lane was automatically assigned to a band class, and all band classes were manually checked and eventually overridden to make them consistent between lanes. The Jaccard coefficient was calculated considering only the presence/absence of bands, each representing an operational taxonomic unit (OTU). Aquatic prokaryotic and eukaryotic communities could be compared thanks to their similarity percentages.

PCR amplification of viral fragments

We first established amplification conditions directly with known viruses of 294 Siphovirus, Myovirus, Podoviruses and PhycoDNAvirus. Then, each concentrated filtrate (50x) 295 from water samples was used as a template with the following program: after initial denaturation at $95^{\circ} \mathrm{C}, 1 \mathrm{~min}$ annealing at $50^{\circ} \mathrm{C}$ and $1.5 \mathrm{~min}$ of extension at $72^{\circ} \mathrm{C}$ for 35 
297 cycles. PCR products were electrophoresed in 1\% agarose gels in TAE buffer. Primers are 298 listed in Table S1.

299 
300

301 [1] Roose-Amsaleg

302

303

304

305

306

307 12476.
C, Yan C, Hoang AM, Laverman AM, Chronic exposure of river sediments to environmentally relevant levels of tetracycline affects bacterial communities but not denitrification rates. Ecotoxicology 2013;22:1467-1478.

[2] van Hannen EJ, van Agterveld MP, Gons HJ, Laanbroek HJ, Revealing genetic diversity of eukaryotic microorganisms in aquatic environments by denaturing gradient gel electrophoresis. J Phycol 1998;34:206-213.

[3] Muyzer G, de Waal EC, Uitterlinden AG, Profiling of complex microbial populations by denaturing gradient gel electrophoresis analysis of polymerase chain reaction-amplified genes coding for 16S rRNA. Appl Environ Microb 1993;59:695-700.

[4] Filée J, Tetart F, Suttle CA, Krisch HM, Marine T4-type bacteriophages, a ubiquitous component of the dark matter of the biosphere. P Natl Acad Sci USA 2005;102:12471-

[5] Parvathi A, Zhong X, Jacquet S, Dynamics of various viral groups infecting autotrophic plankton in Lake Geneva. Adv Oceanogr Limnol 2012;3:171-191.

[6] Larsen JB, Larsen A, Bratbak G, Sandaa RA, Phylogenetic analysis of members of the Phycodnaviridae virus family, using amplified fragments of the major capsid protein gene. Appl Environ Microb 2008;74:3048-3057.

[7] Allen LZ, Ishoey T, Novotny MA, McLean JS, Lasken RS, Williamson SJ, Single Virus Genomics: A new tool for virus discovery. PLoS One 2011;6:1-9. 
323 Fig. S1. DGGE analysis for eukaryotic (A) and prokaryotic (B) plankton from the Marne 324 River at St Maurice screened via their 18S and 16S rRNA gene, respectively. From the 325 bottom to the top of the figure, processed images by Gelcompar II, resulting similarity 326 dendrogams of Jaccard index and histogram of number of OTUs.

328 Fig. S2. Transmission electron microscopy analysis of Saint Maurice water samples.

329 The pies describe viral morphotype compositions of each sample (at least 100 particles were 330 considered).

331

332 Fig. S3. Electron micrograph of concentrated (10,000x) water sample from the Marne River 333 (May $\left.14^{\text {th }}\right)$.

334 Examples of Myovirus and Siphovirus are shown by a white or black arrow, respectively. A 335 membrane vesicle and an untailed virus are shown by a red or green arrow, respectively. 336 Filaments could correspond to free DNA. 
Table S1: List of primers used in this study

339

\begin{tabular}{|c|c|c|c|c|}
\hline $\begin{array}{l}\text { Primer } \\
\text { name }\end{array}$ & Sequences (5'-3') & $\begin{array}{l}\text { Amplicon } \\
\text { size (bp) }\end{array}$ & Target & References \\
\hline F1427-GC & $(\mathrm{GC})_{20}$ TCT GTG ATG CCC TTA GA & 229 & $18 \mathrm{~S}$ ribosomal & [2] \\
\hline R1616 & GCG GTG TGT ACA AAG GG & & & \\
\hline F357-GC & $(\mathrm{GC})_{20}$ CCT AGC GGA GGC AGG AG & 00 & $16 \mathrm{~S}$ ribosomal & [3] \\
\hline R518 & ATT ACC GCG GCT GCT GG & & & \\
\hline MZPA1BF & GAT ATT TGI GGI GGT CAG CCI ATG A & & Major capsid & [4] \\
\hline MZPA1BR & CGC GGT TGA TTT CCA GCA TGA TTT C & 550 & $\begin{array}{l}\text { protein of } \\
\text { Myoviruses }\end{array}$ & \\
\hline Pol F & CCA AAY CTY GCM CAR GT & & DNA & [5] \\
\hline Pol Rb & CTC GTC RTG DAT RAA SGC & & $\begin{array}{l}\text { polymerase of } \\
\text { Podoviruses }\end{array}$ & \\
\hline Mcp F & GGY GGY CAR CGY AAT & & Major capsid & [6] \\
\hline Mcp R & TGI ARY TGY TCR AYI AGG TA & & $\begin{array}{l}\text { PhycoDNAvirus } \\
\text { es }\end{array}$ & \\
\hline lbdintF & TGA TAC TGT GCC GGA TGA AA & & Integrase of & [7] \\
\hline lbdintR & TTA GGC AGA GAC AGG CGA AT & 150 & Siphoviruses & \\
\hline
\end{tabular}




\section{Figure 1}

April $1^{\text {st }}$

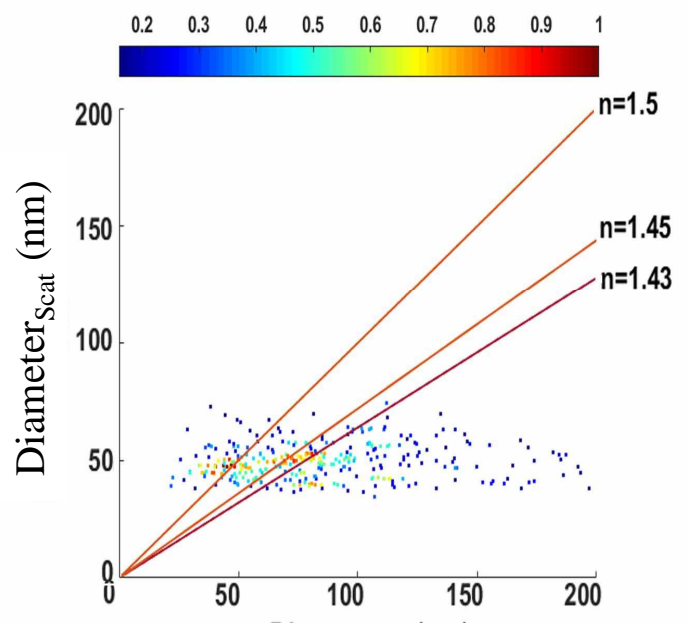

April 22 ${ }^{\text {th }}$

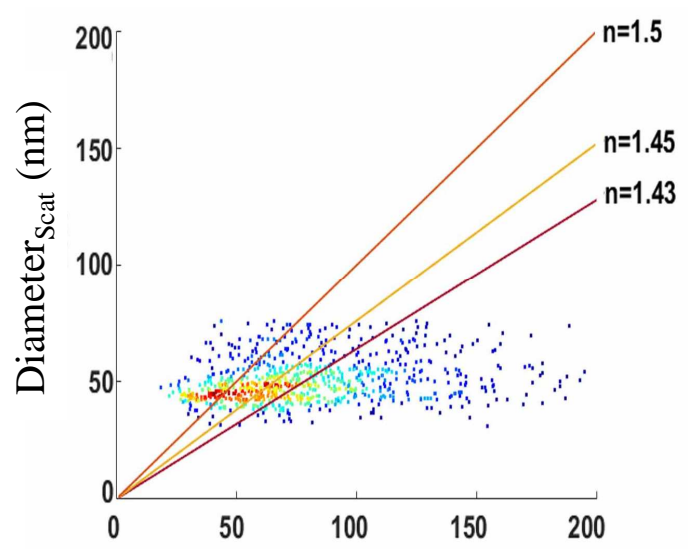

May $14^{\text {th }}$

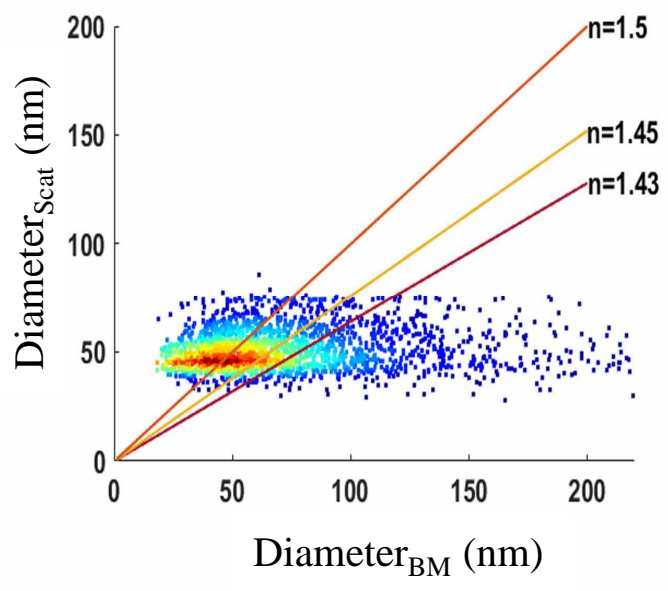


Figure 2
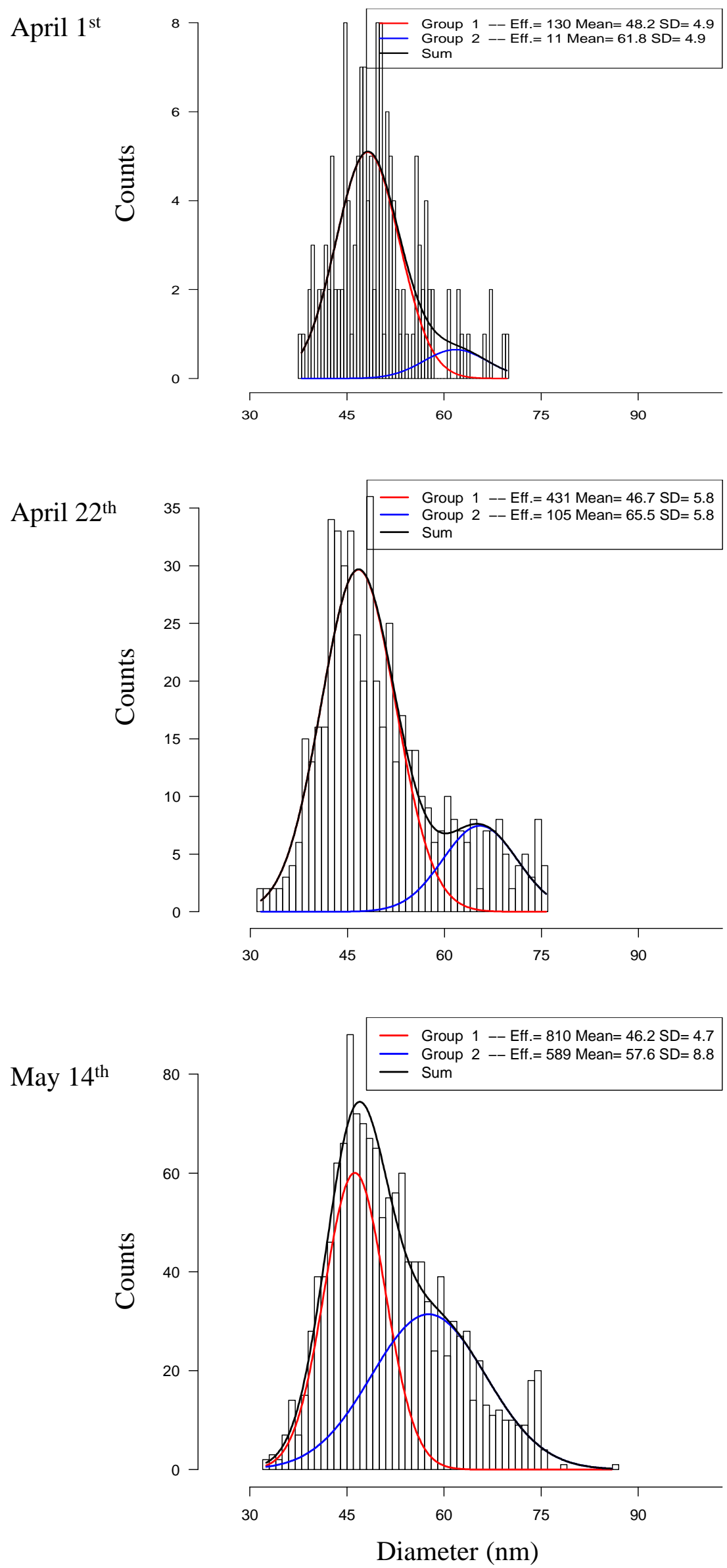